\title{
Genetic Variability Studies on Cowpea Genotypes
}

\author{
M. Pandiyan*, M. Vaithilingan, A. Krishnaveni, P. Sivakumar, C. Sivakumar, \\ E. Jamuna, B. Sivakumar, M. Sivaji, M. Yuvaraj and P. Senthilkumar
}

Plant Breeding and Genetics, Agricultural College Research Institute, Tamil Nadu Agricultural University, Vazhavachanur - 606 753, Thiruvannamalai, India

*Corresponding author

\section{A B S T R A C T}

\section{Keywords}

Variability, heritability, Cowpea, Vigna unguiculata, Genotypes

\section{Article Info}

Accepted:

26 May 2020

Available Online:

10 June 2020
Twenty eight cowpea entries of Agricultural Research Station, Virinjipuram were evaluated for yield and its components during two seasons Kharif 2014 and Rabi 2015. Wide range of variability was observed for various characters. Considerable amount of phenotypic and genotypic variability was observed for seed yield and component characters pods per plant and clusters per plant. The result indicated that the selected cowpea genotypes has shown mean value for 50\% flowering was 45.00 days with total Days 74.50 for full maturity. The plant height was $73.27 \mathrm{~cm}$ with 16.77 no. of pods per plant. In addition 5.42 no. of cluster per plant with 13.50 seeds per pod, $5.84 \mathrm{~g}$ of 100 seed weight and $5.59 \mathrm{~g}$ of single plant yield. High heritability and low genetic advance as percentage of mean were recorded for days to $50 \%$ flowering, days to maturity and plant height suggesting that selection based on these characters could be effective. The character association studies indicated that selection based on days to $50 \%$ flowering, days to maturity, pods per plant, seeds per pod and 100 seed weight along with a medium plant height could useful for improving the yield in cowpea.

\section{Introduction}

Cow (Vigna unguiculata (L.) Walp) is an important pulse crop of India cultivated in all seasons. The cowpea is a predominately hot weather crop. It is more tolerant to drought, infertile soils. Cowpea can be grown quite successfully under conditions that are totally unsuitable for the common bean. The present investigation was undertaken to evaluate available genotypes for yield and its components during Kharif 2014 and 2015 to estimate the variability, heritability and other genetic parameters. The less induction of accessions, lack of information on accessions and region specific seed and agronomic parameters has discouraged the use of exotic parents in cowpea breeding programs.

Genetic variability in yield parameter of cowpea germplasm essential for breeding programs (Ehlers, 1984). 
The cowpea germplasm evaluation and enhancement activities have been promoted by the USDA-ARS Vigna Germplasm Committee. Totally about 1,000 accessions was selected to represent the diversity existing in cowpea for the breeding programmes. Wild cowpeas retain the extensive genetic variability cultivated germplasm ( $\mathrm{Ng}$ and Padulosi, 1988). Genes from wild cowpeas or related Vigna species may be necessary to develop cultivars for better phenotypic and genotypic characteristics.

\section{Materials and Methods}

Fourty cowpea genotypes collected from different locations of Tamil Nadu were grown in a randomized block design with four replications during Kharif 2014 and Kharif 2015 at TNAU, Agricultural Research Station, Virinjipuram, Vellore. Each genotype was sown in a plot of $3 \times 4 \mathrm{~m}^{2}$ in length with $45 \times 15 \mathrm{~cm}$ spacing between and within rows. Observations were recorded on 10 randomly selected plants for each genotype in each replication for plant height (cm), days to $50 \%$ flowering, pods per plant, clusters per plant, seeds per pod, 100 seed weight $(\mathrm{g})$, seed yield $(\mathrm{kg} / \mathrm{ha})$ and days to maturity .Phenotypic and genotypic coefficients of variation and expected genetic advance were estimated as per standard procedure of Johnson et al., (1995).

\section{Results and Discussion}

The variability study was imposed in cowpea for assessing parental ability of the genotypes in future crop improvement programme in cowpea. Eight biometrical characters were recorded. The following parameters namely PCV, GCV, Heritability and Genetic advance and mean percentage for genetic advance were taken for variability study. The highest range of $\mathrm{PCV}$ is observed in the character single plant yield followed by number of cluster per plant, number of pods per plants and days to fifty percent flowering while highest GCV percentage in the following characters namely single plant yield, number of pods per plant followed by number of cluster per plant.

Heritability was higher in number of seeds per pod, plant height, day's full maturity and days to fifty percent flowering. As genetic advance is concern, single plant yield is more followed by number of seeds per plant. The PCV of the selected genotypes was 28.78 for single plants yield (g) whereas the GCV was 15.40 Number of seeds per pod. The Genotype heritability was 48.96 in number of seeds per pod and Genetic advance was $65.87 \mathrm{~g}$ for 100 seed weight. The mean percentage of genetic advance was highest in single plant yield followed by hundred seed eight and number of pods per plant and plant height. The estimates of genetic parameters are presented in Table 1.

The values of phenotypic coefficients of variation are higher than genotypic coefficients of variation indicating the influence of environmental factor. The measure of transmission of a character from parent to off spring is termed as heritability and consistent performance of a character under selection in succeeding generations depends on the magnitude of heritable variation present in relation to the observed variation. The highest genotypic coefficient of variation was observed for seed yield followed by pods per plant and clusters per plant. Thus, there is a scope for improvement of these traits by selection.

Similar results were reported earlier by Joshi et al., (1998). High heritability and low genetic advance for days to $50 \%$ flowering, days to maturity, plant height, suggests nonadditive gene action and indirect selection of 
these traits may be beneficial. High heritability and high genotypic co efficient of variation observed for plant height, this character may effective for selection that showed additive gene action. High heritability and low genetic advance for number of cluster per plant, days to fifty percent flowering and days to maturity suggests non additive gene action and indirect selection of these traits may be beneficial. The observed high genetic advance for single plant yield and number of seeds per pod are important trait for core selection of trait. The high genetic advance as per cent of mean together with high heritability and GCV was noted for number of pods per plant and single plant yield The number of branches per plant high heritability and genetic advance values were reported. In greengram high heritability and genetic advance were also reported Malik and Singh (1983), Renganayaki (1985), Ganesh Ram (1993), Reddy (1997) and Venkateswarlu (2001) for plant height, length of pod, number of clusters per plant and number of pods per plant.

Table.1 Genetic parameters for different characters in cowpea

\begin{tabular}{|l|l|l|l|l|l|l|l|}
\hline Characters & $\begin{array}{l}\text { General } \\
\text { mean }\end{array}$ & Range & PCV & GCV & Heritability & $\begin{array}{l}\text { Genetic } \\
\text { advance }\end{array}$ & $\begin{array}{l}\text { Genetic } \\
\text { advance as } \\
\text { \% of mean }\end{array}$ \\
\hline $\begin{array}{l}\text { Days to 50\% } \\
\text { flowering }\end{array}$ & 45.00 & $38-65$ & 19.00 & 6.00 & 25.00 & 4.25 & $\mathbf{9 . 0 6}$ \\
\hline Days to maturity & 74.50 & $65-97$ & 4.56 & 2.84 & 32.00 & 2.34 & $\mathbf{2 . 2 0}$ \\
\hline Plant height (cm) & 73.27 & $\begin{array}{l}38.30- \\
80.50\end{array}$ & 12.00 & 7.48 & 43.88 & 5.14 & $\mathbf{9 . 7 5}$ \\
\hline $\begin{array}{l}\text { Number of pods } \\
\text { per plant }\end{array}$ & 16.77 & $\begin{array}{l}13.0- \\
20.50\end{array}$ & 23.68 & 11.76 & 32.68 & 2.74 & $\mathbf{1 1 . 4 4}$ \\
\hline $\begin{array}{l}\text { Number of cluster } \\
\text { per plant }\end{array}$ & 5.42 & $4.5-10.50$ & 26.87 & 8.28 & 8.88 & 0.34 & $\mathbf{5 . 1 8}$ \\
\hline $\begin{array}{l}\text { Number of seeds } \\
\text { per pod }\end{array}$ & 13.50 & $7-15$ & 14.94 & 6.84 & $\mathbf{4 8 . 9 6}$ & 6.34 & $\mathbf{3 . 9 6}$ \\
\hline $\begin{array}{l}\mathbf{1 0 0} \text { seed weight } \\
\text { (g) }\end{array}$ & 5.84 & $3.0-8.0$ & 10.56 & 7.84 & 6.12 & 0.46 & $\mathbf{1 1 . 0 6}$ \\
\hline & $\mathbf{5 . 5 9}$ & $\mathbf{4 . 5 4 - 9 . 7 7}$ & $\mathbf{2 8 . 7 8}$ & $\mathbf{1 5 . 4 0}$ & $\mathbf{3 . 7 6}$ & $\mathbf{6 5 . 8 7}$ & $\mathbf{1 6 . 5 3}$ \\
\hline
\end{tabular}

On the basis of the results of the present investigation, it can be concluded that selection based on days to $50 \%$ flowering, days to maturity, plant height, pods per plant, and seeds per pod and seed weight along with a medium plant height.

The highest range of PCV and GCV percentage in the yield attributing parameters like number of pods per plant and number of cluster per plant in the selected genotypes is highly essential for plant breeding programme. In addition, the heritability was higher in seed parameters which could be useful for improving the yield in cowpea.

\section{References}

Ehlers, V.D. and Hall, A.E., 1997. Heat tolerance of contrasting cowpea lines in short and long days. Field Crops Res., in press.

Ganeshram, S. 1993. Evaluation of some genotype's interspecific hybrids and 
derivatives of greengram ( $V$. radiata (L.) Wilczek $\mathrm{x}$ Black gram (Vigna mungo (L.) Hepper) crosses. M.Sc. (Ag.) Thesis, Tamil Nadu Agricultural University, Coimbatore.

Johnson, H.W., H.F. Robinson and R.E. Comstock. 1955. Estimation of genetic variability and environmental variability in soybean. Agron. J., 47: $314-318$.

Joshi, S.N. and M.M.Kabaria. 1973. Interrelationship between yield and yield components in Phaseolus aureus. Roxb. Madras Agric. J., 60: 1331-34.

Malik, BPS. and Singh, VP. 1983. Multiple correlation and regression analysis in greengram. Indian J. Agric. Sci., 53: 400-403.

Ng, N.Q. and Padulosi, S., 1988. Cowpea genepool distribution and crop improvement. In: eds. N.Q. Ng, P. Perrino, F. Attere and H. Zedan, Crop Genetic Resources of Africa, Vol. II, pp. 161-174.

Reddy, KHP. 1997. Genetic divergence in greengram (V.igna radiata (L.) Wilczek). Ann. Agric. Res., 18 (4): 493 $-497$.

Renganayaki, K. 1985. Studies on genetic differentiation between three species of Vigna Savi. M.Sc. (Ag.) Thesis, Tamil Nadu Agricultural University, Coimbatore .

Venkateswarlu, O. 2001b. Genetic variability in greengram (Vigna radiata (L.) Wilczek). Legume Res., 24 (1): 69 - 70.

\section{How to cite this article:}

Pandiyan, M., M. Vaithilingan, A. Krishnaveni, P. Sivakumar, C. Sivakumar, E. Jamuna, B. Sivakumar, M. Sivaji, M. Yuvaraj and Senthilkumar, P. 2020. Genetic Variability Studies on Cowpea Genotypes. Int.J.Curr.Microbiol.App.Sci. 9(06): 3794-3797. doi: https://doi.org/10.20546/ijcmas.2020.906.450 